\title{
The Reviewing Concept of Asymmetric Decentralization in The Special Region of Yogyakarta
}

\section{Triwahyuningsih*)}

\author{
*) Universitas Ahmad Dahlan, Yogyakarta, E-mail: triwahyuningsih@ppkn.uad.ac.id
}

\begin{abstract}
Abtract. The following research aims to analyze the background of the concept of asymmetric decentralization applied in the Special Region of Yogyakarta and aspects of asymmetric authority in the Special Region of Yogyakarta. This research method is normative legal research which is complemented by field research in the form of interviews with related parties. Using a historical approach (historical approach) and legislation (statute approach) It is concluded that the granting of asymmetric decentralization in DIY is due to philosophical, historical, juridical and sociological. The application of asymmetric decentralization in the Special Region of Yogyakarta in the form of the special authority of DIY includes filling in the positions of Governor and Deputy Governor, Regional Institutions, Culture, Land and Spatial Planning. Keywords: Decentralized; Asymmetric; privileged; Policy.
\end{abstract}

\section{Introduction}

The study of decentralization is still growing because many scientists still do not agree on the meaning of decentralization and how to measure decentralization. Aaron Schneider answered the debate by trying to establish a decentralized standard. There are three things that become the benchmark, namely finance, administration, and politics. ${ }^{1}$ Symmetrical decentralization is based on the assumption that all provinces have the same conditions and circumstances. The concept of asymmetric decentralization is characterized by special autonomy. ${ }^{2}$ Cheema and Rondinelli, as quoted by Jusuf Madubun, et al., define decentralization as the transfer of power, authority, and resources through deconcentration, delegation, or co-administration from the center to administrative areas under it. ${ }^{3}$

In principle, asymmetric decentralization is a way of thinking that emphasizes the need to pay attention to differences between regions and the uniqueness of each region, as well as the objective interests of Indonesia as a nation and state. Therefore, the use of the concept of asymmetric decentralization is needed to manage all local diversity, whether reflected in aspects of historical background, culture, economic potential, administrative capacity to certain political demands. ${ }^{4}$ There are two main reasons for implementing asymmetric decentralization, namely asymmetry based on political considerations and administrative needs. ${ }^{5}$ When viewed from the content, the

\footnotetext{
${ }^{1}$ Aaron Schneider. Decentralization: Conceptualization and Measurement. Studies in Comparative International Development, 2003;38:1

${ }^{2}$ Indra Kesuma Nasution. The Challenge of Decentralization in Indonesia: Symmetrical and Asymmetrical Debate. International Journal of Social Science and Humanity 2016

${ }^{3}$ Jusuf Madubun, Haedar Akib, Jasruddin. The Prototype Model of Asymmetric Decentralization in Providing Public Services to the Island Areas. Mediterranean Journal of Social Sciences, 2017;8: 120-123 ${ }^{4}$ Robert Endi Jaweng, Kritik Terhadap Desentralisasi Asimetris di Indonesia", Jurnal Analisis CSIS, Vol 40. No. 2, June 2011.

${ }^{5}$ Ibid
} 
asymmetric substance is reflected in the specificity or privilege of the authority possessed by the asymmetrical region, as well as its linkages in terms of institutions, special funding. ${ }^{6}$ The basis of such asymmetric decentralization can be referred to in the constitution as the supreme legal entity. Asymmetric decentralization concerns fundamental matters related to the pattern of relations between the center and the regions regarding the design of different powers, institutions, finances and controls. ${ }^{7}$ The Special Region of Yogyakarta based on the history of its formation is a special area which includes the Ngayogyakarta Hadiningrat Sultanate and the Paku Alaman Duchy with Sri Sultan Hamengkubuwono IX as Regional Head and Sri Paku Alam VIII as Deputy Regional Head (UU No. 3 of 1950). In one of the considerations of Act No. 13 of 2012 concerning the Privileges of DIY stated that: "The Ngayogyakarta Hadiningrat Sultanate and the Duchy of Pakualaman which already had territory, government and population before the birth of the Unitary State of the Republic of Indonesia on August 17, 1945 played a role and made a major contribution in maintaining, filling, and maintaining the integrity of the Republic of Indonesia. The Unitary State of the Republic of Indonesia. " Since the Giyanti agreement on February 13, 1755, the Ngayogyakarta Hadiningrat Sultanate has had a sovereign and independent government. Since his birth, he has continued to show his resistance to the invaders until the generation of Hamengku Buwono IX. The decision of these two figures has important meaning for Indonesia because it has given real territory and people to Indonesia which has just proclaimed its independence. The role of Yogyakarta continued in the era of the independence revolution which was realized through the efforts of the Sultanate and the Duchy and the people of Yogyakarta in maintaining, filling, and maintaining the integrity of the Unitary State of the Republic of Indonesia.

The problem of the privileges of the Special Region of Yogyakarta becomes interesting when the position of the Sultan who is trying to undermine, by discussing the election of the Governor of the Special Region of Yogyakarta like other regions. As stated by Susilo Bambang Yudhoyono (SBY) "There can be no colliding monarchies, ${ }^{8}$ both with the constitution and democratic values, responding to the Bill on the Privileges of Yogyakarta. The attitude of the government that wants the Governor of DIY not to be held by the Sultan of Yogyakarta because it is the embodiment of the monarchy system which is considered contrary to democracy. In the government's understanding, democracy must be reflected in the filling of the governor's position which is carried out by means of elections, not by determining the Sultan of Yogyakarta who obtains positions based on descent. SBY's statement caused a strong reaction among the people of Yogyakarta9

\footnotetext{
${ }^{6} \mathrm{Ibid}$

7 Bayu Dardias Kurniadi, Desentralisasi Asimetris di Indonesia, http://bdardias.staff.ugm.ac.id/wpcontent/uploads/2008/06/Desentralisasi-Asimetris-di-Indonesia-LAN-Bdg-26112012.pdf, downloaded, 28 July 2019

${ }^{8}$ Ismu Gunadi Widodo, Sistem Penetapan Gubernur Kepala Daerah Istimewa Yogyakarta dalam Sistem Pemilihan Kepala Daerah berdasarkan Pasal 18 ayat (4) UUD 1945, Jurnal Dinamika Hukum Vol 11 No. 2 May, 2011, p. 316-334;

${ }^{9}$ Aidul Fitriciada Azhari. Rekontruksi Tradisi Bernegara Dalam UUD 1945. Yogyakarta: Genta Publishing. 2014, p. 1-2
} 
Meanwhile, Act No. 3 of 1950 concerning the Establishment of the Special Region of Jogjakarta as has been amended several times, most recently by Act No. 9 of 1955 concerning Amendments to Act No. 3 jo. Number 19 of 1950 concerning the Establishment of the Special Region of Yogyakarta refers solely to Act No. 22 of 1948 concerning Regional Government which treats all regions in Indonesia equally and does not fully regulate the features of the Special Region of Yogyakarta. It is stated in Article 1 paragraph (2) of Act No. 22 of 1948 "areas that have rights of origin and in the era before the Republic of Indonesia had special self-government" are those which at the time of the Dutch East Indies government were called "Zelfbesturende landschappen". The purpose of this study is to analyze the reasons why the concept of asymmetric decentralization is applied in the Special Region of Yogyakarta and aspects of asymmetric authority in the Special Region of Yogyakarta.

\section{Research Methods}

This research is a normative legal research which is equipped with field research in the form of interviews with related parties. Using secondary data sources in the form of primary legal materials, namely legislation and secondary legal materials in the form of literature books, theories, journals and other written sources related to the problem being researched..$^{10}$ Using two approaches to obtain information from various aspects regarding the issue that is being tried to answer ${ }^{11}$ namely the historical approach to see the history of the formation of the Special Region of Yogyakarta, because the historical aspect is needed to provide context to the formulation of regulations. That every legal regulation, whatever its form, is the work of humans bound by space and time ${ }^{12}$ and the statutory approach, then data analysis is carried out through systematization, reduction, verification and interpretation of data and then described qualitatively.

\section{Results and Discussion}

\subsection{Asymmetrical Decentralization in DIY}

Based on Article 18 B paragraph (1) of the 1945 Constitution of the Republic of Indonesia, "The State recognizes and respects special or special regional government units which are regulated by law." One of the laws governing special regional government units is Act No. 13 of 2012 concerning the Privileges of the Special Region of Yogyakarta. As stated in Article 1 paragraphs (1) and (2) "The Special Region of Yogyakarta, hereinafter referred to as DIY, is a provincial area that has privileges in administering government affairs within the framework of the Unitary State of the Republic of Indonesia.

The description of the Ngayogyakarta Hadiningrat Sultanate in the Unitary State of the Republic of Indonesia will not be separated from the historical aspect of the joining of the Ngayogyakarta Hadiningrat Sultanate in the Unitary State of the Republic of Indonesia. Sultan Hamengku Buwono IX and Paku Alam VIII asserted themselves as part

\footnotetext{
${ }^{10}$ Khudzaifah Dimyati dan Kelik Wardiyono, Metode Penelitian Hukum, Surakarta : FH UMS, 2014, p. 14

${ }^{11}$ Peter Mahmud, Penelitian Hukum, Jakarta : Kencana, 2017, p. 133

${ }^{12}$ Sidharta, Hukum Penalaran dan Penalaran Hukum, Yogyakarta : Gentha Publishing, 2013,

p. $258-259$
} 
of the newly proclaimed Republic of Indonesia while still controlling and leading their traditional territories as a special part of the Republic of Indonesia through a decree dated September $5,1945 .{ }^{13}$ This edict was able to confirm the existence of the Sultanate and Pakualaman in the Republic of Indonesia. The mandate of 5 September 1945 the two rulers of the Sultanate and Duchy in Yogyakarta were:

"First, that the State of Ngayogyakarta Hadiningrat as a Kingdom is a special area of the Republic of Indonesia. Second, that we as the Regional Head hold all the power in the Ngayogyakarta Hadiningrat State. Therefore, due to the current situation, all government affairs in the State of Ngayogyakarta Hadiningrat are now in our hands and all other powers are in our hands. Third, that the relationship between the State of Ngayogyakarta Hadiningrat and the Central Government of the Republic of Indonesia is direct and we are responsible for our country directly to the President of the Republic of Indonesia. ${ }^{14}$

The central government positively welcomed the mandate of the two rulers. The next day, September 6, 1945, two delegates from the central government, the Ministers of State Mr. Sartono and Mr. AA Maramis came to Yogyakarta to deliver the "Determination Charter" regarding Yogyakarta's position within the Republic of Indonesia which was signed by President Soekarno on August 19, 1945 or meaning the day after the first congratulatory wire was sent from Sultan Hamengku Buwono IX to Sukarno-Hatta. The charter states): We, the President of the Republic of Indonesia, stipulate:

"Ingkang Sinuwun Kanjeng Sultan Hamengku Buwono Senopati Ing Ngalaga Abdurrakhman Sayidin Panatagama Kalifatullah ingkang kaping IX ing Ngayogyakarta Hadiningrat, pada kedudukannya, dengan kepercayaan bahwa Sri Paduka Kanjeng Sultan akan mencurahkan segala pikiran, tenaga, jiwa dan raga untuk keselamatan daerah Yogyakarta sebagai bagian daripada Republik Indonesia." ${ }^{15}$ (Original Text)

While Sultan Hamengku Buwono IX was an intelligent person, not a pragmatic person who used his status not only to support the Republic of Indonesia during the revolutionary period, but also to maintain its political status and mainly to defend its principles which in the end was able to defend its traditional territory, as said ${ }^{16}$ :

"Hamengkubuwono was a politically astute, non-ideological pragmatist who cleverly used his ascribed status as Sultan not only to support the Republican cause during the revolution, but also to ensure his own political survival and, ultimately, to preserve his principality"

\footnotetext{
${ }^{13}$ Bayu Dardias, “Menyiapkan Sultan Perempuan: Legitimasi Langit dan Efektivitas Rezim Sultan HamengkuBuwono X, "Jurnal Masyarakat Indonesia, Vol 42 (1), June 2016, p. 33 http://bayudardias.staff.ugm.ac.id/wpcontent/uploads/2017/02/Bayu-Dardias-2016-Menyiapkan-

Sultan-Perempuan-Legitimasi-Langit-DanKekuatan-Regim-Sultan-Hemengkubuwono-X.Pdf

${ }^{14} \mathrm{Ni}^{\prime}$ matul Huda, Desentralisasi Asimetris dalam NKRI, Bandung : Nusa Media, 2014hlm. 123, Ni'matul Huda, Daerah Istimewa Yogyakarta dalam Perdebatan Konstitusi dan Perundang-undangan di Indonesia.Bandung: Nusa Media, 2013, p. 60-61

15 Ibid.

${ }^{16} J o h n$ Monfries , A Prince in a Republic: The Life of Sultan Hamengku Buwono IX of Yogyakarta, Singapore : Institute of Southeast Asian Studies, 2015, p. 123
} 
It is for historical reasons that the status of "special area" was given to the Ngayogyakarta Hadiningrat Sultanate, which is now called the Special Region of Yogyakarta, because of the role and contribution of the Ngayogyakarta Hadiningrat Sultanate in maintaining, filling and maintaining the integrity of the Unitary State of the Republic of Indonesia. As stated by Mr. Soedarisman Poerwokoesoemo ${ }^{17}$

"Negara Republik Indonesia menghormati kedudukan daerah-daerah istimewa dan segala peraturan negara mengenai hal daerah itu akan mengingat hak-hak asal usul daerah tersebut. Hal ini untuk menjaga keseimbangan politik dan sangat sadar wilayah itu dulunya bernama Hindia Belanda (zelfbesturende landschapaen). Namun ternyata bahwa proklamasi kemerdekaan segera dikuti revolusi. Semua swapraja tergilas roda revolusi, kecuali swapraja Kasultanan Ngayogyakarta dan Palualaman yang segera setelah proklamasi bersatu menyambut dan menyatakan diri sebagai bagian dari Rebublik Indonesia". (Original Text)

Based on that historical evidence that after the Proclamation of Independence on August 17, 1945 "the Ngayogyakarta Hadiningrat Sultanate voluntarily declared it to join and become an integral part of the Unitary State of the Republic of Indonesia even though at that time the Ngayogyakarta Hadiningrat Sultanate already had its own territory, population and government." This means that the Ngayogyakarta Hadiningrat Sultanate is a country that existed before the formation of the Republic of Indonesia. In accordance with the opinion of Peter Carey $(2018)^{18}$ that "the Javanese constitutional concept defines the state as a unit that has obtained the right to a monopoly of power in a certain geographical area". In the historical aspect it means that Yogyakarta is special, because the Sultan who reigns in the Ngayogyakarta Hadiningrat Sultanate is not a "gift" or formed by the State (in casu the Unitary State of the Republic of Indonesia). On the contrary, it was precisely because of the voluntary actions of the Sultan who was on the throne at that time that the Special Region of Yogyakarta became an integral part of the Unitary State of the Republic of Indonesia.

Philosophically, the wise choice to become part of the Unitary State of the Republic of Indonesia is a reflection of the philosophy of the Sultanate, Pakualaman and the people of Yogyakarta as a whole which upholds the concept of Bhinneka Tunggal Ika as stated in Pancasila and the 1945 Constitution. Philosophy to build the small world of Yogyakarta and the big world of Indonesia. The philosophy puts forward a larger interest, namely the Unitary State of the Republic of Indonesia from a small one, namely Yogyakarta, giving up some of its power to Indonesia, from the power of the Ngayogyakarta Sultanate.

The juridical argument began when President Soekarno gave the "State Charter" to the rulers of the Ngayogyakarta Hadiningrat Sultanate on August 19, 1945, which was a sign of Indonesia's trust in Hamengku Buwono IX. The mandate of 5 September 1945 stated that the Ngayogyakarta Hadiningrat Sultanate in the form of a kingdom was a Special

\footnotetext{
${ }^{17}$ Soedarisman Poerwokoesoemo. Kasultanan Yogyakarta, Yogyakarta: Gadjah Mada University Prees. 1985, p. 64

${ }^{18}$ Peter Carey, Pengantar buku Soemarsaid Moertono, Negara dan Kekuasaan di Jawa Abad XVI-XIX, Jakarta: Kepustakaan Populer Gramedia, 2018, p. xv
} 
Region, part of the Republic of Indonesia and all domestic power and government affairs were in the hands of Hamengku Buwono IX. The status of the Ngayogyakarta Sultanate from a formal juridical aspect, has undergone a change from Zelfbesturende Landschappen or a Swapraja area to a Special Region within the scope of the Republic of Indonesia.

Based on the historical fact that this Special Region already has rights and authority in the administration of various government affairs in its area, both gifts from the government and rights that have been owned since the beginning before joining the Republic of Indonesia (autochtoon). According to Sujamto. ${ }^{19}$ These rights include: (1) the right of origin regarding the institutional structure (2) procedures for the appointment and dismissal of leaders (3) the administration of government affairs, especially those related to the administration and burdening of the community.

State recognition of the existence of the Ngayogyakarta Hadiningrat Sultanate through various constitutions that have been in force in Indonesia (UUD NRI 1945, UUD RIS, UUDS, UUDNRI post-Amendment) and legal products regarding regional government in Indonesia, namely Act No. 22 of 1948, USSU No. 1 of 1957, Presidential Decree No. 6 of 1959, Act No. 18 of 1965, Act No. 5 of 1974, Act No. 22 of 1999, Act No. 32 of 2004 and Act No. 3 of 1950 concerning the Establishment of DIY in conjunction with Act No. 19 of 1950 in conjunction with Act No. 9 of 1955 and Act No. 13 of 2012 concerning the Privileges of the Special Region of Yogyakarta.

Sociological aspects, that the position of the Sultanate socio-culturally is a standard institution for the people of Yogyakarta which is believed to be a source of value and as a protector of the community. The religious-magical (transcendent) power of the Sultanate reflects the balance of the outer and inner world, therefore its position is placed in the highest position and is believed to be the source of truth. There is no conflict between Kaula and Gusti, because Gusti's existence alone is for the greatest prosperity of Kaulo. The sociological aspect also illustrates the strong relationship between the people of Yogyakarta and the Sultanate, through 'Pisowanan Ageng', Ismaya (Ing Sedya Memetri Aslining Ngayogyakarta) cultural rituals, non-violent peaceful actions against the 'orders' or orders of the Sultan. Overall, the Sultanate and Pakualaman are still believed by the people of Yogyakarta as the epicenter,

\subsection{Asymmetric Decentralization Study in DIY}

It is regulated in Article 1 paragraph (3) of Act No. 13 of 2012 concerning the Privileges of DIY that "Special Authority is a certain additional authority that is owned by DIY other than the authority as specified in the law on regional government". This additional authority is embodied in the concept of asymmetric decentralization, which means the transfer of special powers that are only given to certain regions in order to maintain the existence of regions within the Unitary State of the Republic of Indonesia. ${ }^{20}$

In principle, a unitary state is a state whose sovereignty is not divided, or in other words, a state whose powers of the central government are not limited because the

\footnotetext{
${ }^{19}$ Sujamto, Daerah Istimewa Dalam Negara Kesatuan Republik Indonesia, Jakarta : Bina Akasara, 1988, p. 15

${ }^{20} \mathrm{Ni}$ 'matul Huda, Op.Cit, p. 4
} 
constitution of a unitary state does not recognize the existence of a law-making body other than a central legislator. ${ }^{21}$. The constitution is used as the highest grip because the constitution describes positive law at the highest level ${ }^{22}$ in deciding everything that must be based on law. According to Abu Daud Busroh ${ }^{23}$

"A unitary state is a state that is not composed of several states, but rather a single state, meaning that there is only one state, no state within a state. Therefore, in the unitary state there is only one government, namely the central government which has the highest power or authority in all fields of government. It is this central government that at the last and highest level can decide everything in the country." 24

In a unitary state, the central government exercises the highest power of the state, as stated by Ni'matul Huda: ${ }^{25}$

"In a unitary state, the central government exercises the highest sovereignty of the state. In order not to be arbitrary, the activities of the central government are monitored and limited by law. The logical consequence of its position as the organizer of state sovereignty is that government units that are formed and are under the central government must submit to the central government. Without organizational submission and compliance based on applicable laws and regulations, there will be overlaps and collisions in the exercise of authority (the principle of unity of commond)."

The concept of asymmetric decentralization was then used to explain the powers granted by the central government to the Special Region of Yogyakarta through Act No. 13 of 2012 concerning the Privileges of the Special Region of Yogyakarta.

\subsection{Authority in DIY Privileges}

As regulated in Article 7 paragraph (1) of Act No. 13 of 2012 concerning the Privileges of the Special Region of Yogyakarta, that the authority of the Special Region of Yogyakarta as an autonomous region includes the authority in the affairs of the DIY Regional Government as regulated in the Law on Regional Government and Privileges as regulated in Act No. 13 of 2012. Furthermore, the authority in matters of Privileges includes: (a) procedures for filling in the positions, positions, duties and authorities of the Governor and Deputy Governor; (b) DIY Regional Government institutions; (c) culture; (d) land; (e) spatial planning. It was determined that the administration of authority in Privileged matters was based on the values of local wisdom and partisanship with the people.

Article 22 Special Regional Regulation No. 1 of 2013 concerning the Authority in the Special Affairs of the Special Region of Yogyakarta as amended by the Regulation of the Special Region of the Special Region of Yogyakarta Number 1 of 2015 concerning the Amendment to the Regulation of the Special Region of the Special Region of Yogyakarta Number 1 of 2013 concerning the Authority in the Special Affairs of the Special Region of Yogyakarta, a Regional Regulation is stipulated Special No. 2 of 2015 concerning

\footnotetext{
${ }^{21}$ lbid., p. 5

${ }^{22}$ Kelsen, Hans, Introduction to the Problems of Legal Theory (Clarendon Press- Oxford), penerjemah Siwi Purwandari, Pengantar Ilmu Hukum, Bandung : Nusa Media, 2012, p.102

${ }^{23}$ Abu Daud Busroh, Ilmu Negara, First Edition, Jakarta : Bumu Aksara, 1990, p. 64-65

${ }^{24}$ Ibis.

${ }^{25} \mathrm{Ni}$ 'matul Huda, Loc. Cit.
} 
Procedures for Filling the Position, Inauguration, Position, Duties, and Authorities of the Governor and Deputy Governor.

3.3.1. Procedures for Filling the Positions, Inauguration, Position, Duties, and Authorities of the Governor and Deputy Governor are regulated in Perdais No. 2 of 2015.

The requirements for filling the position of Governor of DIY are Indonesian citizens who meet the following requirements: "a. devoted to God Almighty; b. loyal to Pancasila as the basis of the state, the 1945 Constitution of the Republic of Indonesia, the ideals of the Proclamation of August 17, 1945, and the Unitary State of the Republic of Indonesia, as well as the Government; c. enthroned as Sultan Hamengku Buwono for the candidate for Governor and enthroned as Duke of Paku Alam for the candidate for Deputy Governor; $d$. educated at least high school or equivalent; e. at least 30 (thirty) years old; f. physically and mentally capable based on the results of a thorough medical examination from a team of doctors/government hospitals; $g$. has never been sentenced to imprisonment based on a court decision that has obtained permanent legal force for committing a crime punishable by imprisonment of 5 (five) years or more, unless the person concerned has finished serving a sentence of more than 5 (five) years and announces openly and honestly to the public that he has been a convict and will not repeat the crime; $h$. not being deprived of their right to vote based on a court decision that has permanent legal force; $i$. submit a list of personal assets and are willing to be announced; $j$. not currently having debt obligations individually and/or as a legal entity which is their responsibility which is detrimental to state finances; $k$. not being declared bankrupt based on a court decision that has permanent legal force; I. have a taxpayer identification number (NPWP); $m$. submit a curriculum vitae containing, among others, educational, occupational, sibling, and child history; n. no political members ${ }^{26}$.

The nomination letter for the candidate for Governor was signed by Penghageng Kawedanan Hageng Registrar of the Kasultanan Ngayogyakarta Hadiningrat and the nomination letter for the candidate for Deputy Governor signed by Penghageng (Perdais Kawedanan Hageng Kasentanan of the Pakualaman Duchy; and a statement of willingness of Sultan Hamengku Buwono who was enthroned as a candidate for Governor and Duke of Paku Alam who served as a candidate for Governor and Duke of Paku Alam who enthroned as a candidate for Deputy Governor. ${ }^{27}$. Furthermore, the Sultanate and the Duchy are obliged to fulfill the requirements for the candidates for governor and candidates for deputy governors as referred to in Article 3 above. It was also explained that the reigning Sultan Hamengku Buwono was the Sultan who was jumeneng as Sultan Hamengku Buwono in accordance with the paugeran and traditional processions of the Sultanate (Articles 4 and 5). Next, it is regulated on the procedure for submitting candidates for governor and deputy governor candidates and their verification ${ }^{28}$ and Determination of Governor and Deputy Governor ${ }^{29}$

\footnotetext{
${ }^{26}$ Perdais No. 2 Of 2015

${ }^{27}$ Article 3 Perdais No. 2 Of 2015

${ }^{28}$ Article 7-12 Perdais No. 2 Of 2015

${ }^{29}$ Article 13 Perdais No. 2 Of 2015
} 
The term of office of the Governor and Deputy Governor of DIY is different from the term of office of the Governor and Deputy Governor in other provinces in Indonesia which can be held for a maximum of 2 terms. The term of office of Sultan Hamengku Buwono who reigns as Governor and Duke of Paku Alam who reigns as Deputy Governor for 5 (five) years from the inauguration and is not bound by the provisions of 2 (two) terms of office. ${ }^{30}$ This Perdais also regulates "Filling the Positions of Governor and Deputy Governor in certain circumstances". In the event that the enthroned Sultan Hamengku Buwono meets the requirements as a candidate for Governor and the reigning Duke of Paku Alam does not meet the requirements as a candidate for Deputy Governor, the DPRD shall determine Sultan Hamengku Buwono who is enthroned as Governor as well as carrying out the duties of the Deputy Governor until the inauguration of the Duke of Paku Alam who is enthroned as Deputy Governor. On the other hand, if Sultan Hamengku Buwono does not meet the requirements as a candidate for governor and Adipati Paku Alam meets the requirements as a candidate for Deputy Governor, the DPRD will appoint Adipati Paku Alam as Deputy Governor and carry out his duties as Governor until the inauguration of Sultan Hamengku Buwono who is enthroned as Governor (Article 15). ${ }^{31}$

\subsubsection{DIY Regional Government Institutions}

The background of the regulation regarding the DIY Regional Government Institutions is Article 30 paragraph (2) of Act No. 13 of 2012 concerning the Privileges of the Special Region of Yogyakarta and Article 3 paragraph (1) of Government Regulation Number 18 of 2016 concerning Regional Apparatus and the provisions of Article 5 paragraph (1) Regulation of the Minister of Home Affairs Number 8 of 2017 concerning Institutional Government of the Special Region of Yogyakarta 32

Institutional Government of the Special Region of Yogyakarta which is regulated in Perdais No. 1 of 2018 includes: the establishment of Regional Apparatus; position in Regional Apparatus; and Parampara Praja (Article 3). In carrying out the privileged affairs to provide considerations, suggestions and opinions to the Governor, Parampara Praja is formed. Parampara Praja has a maximum of 9 (nine) members consisting of academics/technocrats, elements of the Sultanate and elements of the Duchy, as well as community leaders who are elected and appointed by the Governor (Article 22). So Parampara Praja is "a non-structural institution that has the task and function of providing considerations, suggestions and opinions regarding matters of privilege to the Governor of DIY".

General Explanation of Perdais No. 1 of 2018 states "That the DIY Regional Government institutions have been stipulated by the Yogyakarta Special Region Regulation Number 3 of 2015 concerning the DIY Regional Government Institutions. Based on the evaluation, the DIY Regional Regulation Number 3 of 2015 concerning Regional Government Institutions needs to be improved regarding the association, the number of structures by taking into account the principles of rightsizing and regrouping which is guided by the magnitude of the workload of each Regional Apparatus."

\footnotetext{
${ }^{30}$ Article 14 Perdais No. 2 Of 2015

${ }^{31}$ Article 16 Perdais No. 2 Of 2015

${ }^{32}$ See Perdais No. 1 Of 2018)
} 
"The DIY Regional Government Institution is one of the privileges regulated in the Perdais, so to accommodate the provisions of Article 30 of Act No. 13 of 2012 concerning the Privileges of DIY, that institutional authority is held to achieve effectiveness and efficiency of government administration and public services based on the principle of responsibility, accountability, transparency and participation by taking into account the original form of government. This privilege in institutional authority is emphasized by the Minister of Home Affairs Regulation Number 8 of 2017 concerning the Institutions of the Yogyakarta Special Region Government in Article 2 which is used as the basis for the DIY Regional Government and the DIY DPRD in forming the DIY Regional Government institutions. ${ }^{33}$

\subsubsection{Culture}

Cultural authority is regulated in Act No. 13 of 2012 Article 31, DIY Parent Regulation No. 1 of 2013 amended by Perdais No. 1 of 2015 concerning Authority in Special Affairs of DIY and DIY Perdais No. 3 of 2017 concerning the Maintenance and Development of DIY Culture.

The background of the regulation regarding the Maintenance and Development of DIY Culture, among others, the Ngayogyakarta Hadiningrat Sultanate, hereinafter referred to as the Sultanate, is the nation's cultural heritage that has been passed down from generation to generation and is led by "Ngarsa Dalem Sampeyan Dalem Ingkang Sinuwun Kanjeng Sultan Hamengku Buwono Senapati Ing Ngalaga Ngabdurrakhman Sayidin Panatagama Kalifatullah, hereinafter referred to as Sultan Hamengku Buwono." Cultural authority is held to maintain and develop the results of creativity, taste, initiative and work in the form of values, knowledge, norms, customs, objects, arts, and noble traditions rooted in the DIY community. ${ }^{34}$.

Perdais No. 3 of 2017 concerning the Maintenance and Development of Culture, Article 1 (1) Perdais No. 3 of 2017 "Culture is everything related to creativity, taste, initiative, and work through a learning process that is rooted in the people of the Special Region of Yogyakarta." "The arrangement for the maintenance and development of culture is carried out based on the following principles: a. openness to other cultures; $b$. ability to cultivate culture; c. dialogical awareness; d. strong personality; e. continuity; and f. independent cultural unity." (Section 2). The "Culture Maintenance and Development Arrangements" are aimed at:

"Strengthening the character and identity of the community; realizing the maintenance of the cultural values of DIY in the life of the community, institutions, and government; develop DIY culture to increase the cultural resilience and contribution of DIY culture in the midst of world civilization; realize equal access to cultural activities and increase appreciation of arts and creativity of cultural works; and improve the welfare of society." (Article 3)

Cultural objects of the Special Region of Yogyakarta include: a. cultural values; $b$. knowledge and technology; c. language; d. customs; e. noble tradition; f. object; and g. art (Article 5). Duties and authorities of the Regional Government (Article 25-31) as well as the roles and responsibilities of the Sultanate and Duchy (31-32) as well as the roles

\footnotetext{
${ }^{33}$ General Explanation of Perdais No. 1 Of 2018

${ }^{34}$ Article 30 paragraph (1) of Act No. 13 Of 2012
} 
and responsibilities of the community (Article 33) in the maintenance and development of Culture.

In the General Explanation of Perdais No. 3 of 2017 states that: "Yogyakarta memiliki Kebudayaan khas yang sarat dengan nilai-nilai luhur. Nilai-nilai luhur tersebut telah dijadikan landasan filosofis oleh Sultan Hamengku Buwono I ketika beliau mulai membangun Nagari Ngayogyakarta Hadiningrat sebagai pemerintahan, masyarakat, dan wilayah yang mandiri. Nilai-nilai adiluhung seperti Hamemayu Hayuning Bawana, Mangasah Mingising Budi, Memasuh Malaning Bumi, Golong Gilig, serta sifat-sifat satriya yang berpegang pada etos Sawiji, Greget, Sengguh, Ora Mingkuh telah terwujud dalam kehidupan masyarakat maupun penataan ruang wilayah yang kini dikenal sebagai DIY. Nilai-nilai luhur yang juga dipercayai sebagai kearifan lokal (local wisdom) selain memiliki cakupan keberlakuan di DIY, juga dapat disejajarkan sebagai nilai-nilai budaya nasional atau bangsa dalam kerangka Negara Kesatuan Republik Indonesia." (Original Text)

In addition, the General Explanation of Perdais No. 3 of 2017, it is explicitly stated that Yogyakarta's culture is a legacy of the Islamic Mataram Kingdom, as follows: "Yogyakarta culture is understood as noble basic values created by creativity and taste that are manifested in the intentions and works that become the identity of the people of Yogyakarta. From the history of its formation, Yogyakarta Culture was initiated and enriched by various sources, such as: "the noble values of the Islamic Mataram Kingdom in Kotagede; the city administration design created by Prince Mangkubumi known as associative saujana (associate cultural landscape) which refers to the imaginary axes of two great natural forces, namely Segara Kidul in the south and Mount Merapi in the north; elements of foreign cultures such as Colonial, Indies, and Chinese cultures. The main source that enriches Yogyakarta Culture from its history to the present is the Culture of the Sultanate and Duchy."

The inclusion of the noble values of the Islamic Mataram Kingdom implies that these values must be maintained, developed both by the Regional Government, Sultanate and Duchy as well as by community members in accordance with their respective roles and responsibilities to strengthen the identity of the people of the Special Region of Yogyakarta and to counteract the values of the people of the Special Region of Yogyakarta. -Other values that are not in accordance with the character and identity as the identity of the people of Yogyakarta. The importance of maintaining Islamic values in the Ngayogyakarta Hadiningrat Sultanate was also conveyed by Afnan Hadikusumo ${ }^{35}$ (2019) that the title of Khalifatullah must remain attached to the future Sultan, because he is the heir to the Islamic Mataram kingdom which still exists to this day. Therefore, Yogyakarta culture is used as one of the norms of family, community and state life, in addition to religious norms and legal norms, as well as realizing community welfare.

In the future, there must be a constitutional legal status that regulates the Ngayogyakarta Sultanate as a cultural center, so that the noble cultural heritage can be well preserved. This means that with Act No. 13 of 2012 concerning the Privileges of DIY

\footnotetext{
${ }^{35}$ Interview with Afnan Hadikusuma, Member of DPD RI Dapil DIY 27 July 2019.
} 
is not enough, there must be a separate law that regulates the Culture of the Ngayogyakarta Hadiningrat Sultanate. ${ }^{36}$

\subsubsection{Land}

The Sultanate and Duchy as legal entities are subject to rights that have ownership rights to land in the Sultanate and Duchy. Article 32 of Act No. 13 of 2012 "Kasultanan land and Duchy land consist of Keprabon land and non-Keprabon land located in all regencies/cities in the Special Region of Yogyakarta. "Both the Sultanate and the Duchy are authorized to manage and use the land for cultural development, social interests and community welfare. "The land ownership rights of the Sultanate and the Duchy must be registered with the land agency in accordance with the laws and regulations, if it is carried out by another party, it must obtain written approval from the Sultanate for the Sultanate land and written approval from the Duchy for the Duchy land.

At first, all land in the Yogyakarta area before being designated by Rijksblad Sultanate Number 16 of 1918 in conjunction with Number 23 of 1925 is the property of the Sultan as the ruler of the Sultanate of Ngayogyakarta Hadiningrat. The people are only given the right to anggadhuh or to borrow land and are subject to the obligation to give part of their cultivation to the Sultan as the owner ${ }^{37}$. Article 1 of the Rijksblad of the Sultanate Number 16 of 1918 reads: "Ingsun nglestarekake watone sakabehe bumi kang ora ana tandha yaktine Kadarbe liya mawa eigendom authority, dadi bumi kagungan Karatoningsun Ngayogyakarta" (I determine the boundaries of all land that has no sign of property rights based on eigendom, is Ngayogyakarta Palace).

Land that is directly controlled by the king is called land maosan/pamahosan dalem. In addition to the maosan dalem land, there is also kejawen land or lungguh land or gadhuhan land (apanage), which is land used to guarantee the needs of the royal family, or to pay the courtiers. The royal family or abdi dalem who received the land were called obedient or obedient lurah whose rights and obligations were contained in the obedient institution from $1863^{38}$.

The development of the Ngayogyakarta Sultanate's rights to the Sultanate's land cannot be separated from the history of the establishment of the Special Region of Yogyakarta which began with the mandate of 5 September 1945 by Sultan Hamengku Buwono IX and Paku Alam VIII. In the mandate it was emphasized that the Ngayogyakarta Hadiningrat Sultanate and the Paku Alaman Duchy were part of the Republic of Indonesia. Based on the above mandate, the Special Region of Yogyakarta (DIY) was formed whose territory included the Ngayogyakarta Sultanate and the Paku Alaman Duchy. The formation of DIY was further strengthened by Act No. 3 of 1950 concerning the Establishment of the Special Region of Yogyakarta.

Through Act No. 3 of 1950 in conjunction with Act No. 19 of 1950 set household affairs for DIY, so that land issues became the authority of regional autonomy. Furthermore, it is regulated in the DIY Regional Regulation Number 5 of 1954. In Article 2 of the DIY Regional Regulation No. 5 of 1954 it was determined that the land rights in DIY still apply

\footnotetext{
${ }^{36}$ Interview with Peter Carey, International Symposium on Javanese Studies and Manuscript of Yogyakarta Palace, Royal Ambarukmo Yogyakarta, 5-6 March 2019

${ }^{37}$ Soedikno Mertokusumo, Perundang-undangan Agraria Yogyakarta, Yogyakarta : Liberty, 1998, 1998, p. 26

${ }^{38} \mathrm{Ibid}$, p. $26-27$
} 
the regulations as contained in the Rijksblad Kasultanan No. 16 of 1918 jo Rijksblad Sultanate No. 23 of 1925 and Rijksblad Paku Alaman No. 25 of 1925. In the Rijksblad it was determined that the land for which there was no proof of ownership rights was the land of the Ngayogyakarta Sultanate or the land of the Paku Alaman Duchy. Based on the provisions as stated in Article 2 of the DIY Regional Regulation above, the Ngayogyakarta Sultanate is still recognized as having ownership rights over the land, namely the holder of property rights (subject rights) of the Sultanate land. Land regulations in DIY as regulated in Perda no. 5 of 1954 is valid until September 24, 1984, meaning that the Sultanate of Ngayogyakarta until September 24, 1984 is domiciled as the subject of property rights, with the Sultanate's land as the object of its rights. ${ }^{39}$

The enactment of the UUPA in DIY on September 24, 1984, legally made the Ngayogyakarta Sultanate no longer domiciled as a the subject of land ownership rights, however, sociologically, the people of Yogyakarta still recognize that the Sultanate is the owner of the land of the Sultanate, which is a legal reality (the living law) that must be respected. That is, the people of Yogyakarta still recognize that the subject of property rights to land, with the land of the Sultanate as the object of their rights. This can be seen from the procedures for using the land of the Ngayogyakarta Hadiningrat Sultanate by the people of Yogyakarta which is always preceded by an application to the Ngayogyakarta Sultanate as the land owner. ${ }^{40}$

The land issue in DIY has obtained a strong juridical basis with the issuance of Act No. 13 of 2012 concerning the Privileges of DIY has given several special powers in DIY, including land issues. Furthermore, it has been stated in detail in the RegulationsDIY Special Region (DIY Perdais) No. 1 Year 2017. Sultanate land and land Duchy is land owned by the Sultanate and Duchy which includes Land of Keprabon and Land of Non-Keprabon or Dede Keprabon located in districts/cities within the territory of DIY. ${ }^{41}$. Management and utilization of Sultanate Land and Duchy Land based on the principles:

"a. recognition of origin rights; $b$. government effectiveness; and c. utilization of local wisdom, which in its implementation pays attention to the values of: $a$. local wisdom; $b$. noble culture; c. people welfare; $d$. Justice; e. legal certainty; f. good administration; and g. openness." ${ }^{\prime 42}$.

In CHAPTER III Article 5 Perdais No. 1 of 2017 states that "The Sultanate and Duchy are established as legal entities based on the Law. The Sultanate and the Duchy as legal entities are subject to land ownership rights, namely the Sultanate Land for the Sultanate and the Duchy Land for the Duchy." The Sultanate Land and Duchy Land consist of: "a. Tanah Keprabon; dan b. Tanah Bukan Keprabon atau Dede Keprabon, yang terdapat di seluruh kabupaten/kota dalam wilayah DIY. Tanah Keprabon merupakan tanah yang dipergunakan maupun Kadipaten untuk bangunan istana dan kelengkapannya. Tanah Keprabon Kasultanan meliputi ": a. Karaton; b. Alun-alun Lor; c. Alun-alun Kidul; d. Benteng; e. Jagang; f. Panggung Krapyak; g. Tugu Pal Putih; $h$. Tamansari; i. Pasar Beringharjo; j. Kepatihan; k. Pasareyan Imogiri Ngayogyakarta; I.

\footnotetext{
${ }^{39}$ Djoko Sukisno. 2011. Disertasi, Kedudukan Kasultanan Yogyakarta Sebagai Subjek Hak Atas Tanah Sebelum Dan Sesudah Berlakunya UU No. 5 Tahun 1960 Di Daerah Istimewa Yogyakarta, FH UNDIP ${ }^{40}$ Ibid.

${ }^{41}$ Article 1 Special Region Regulation of DIY (Perdais DIY) No. 1 Of 2017

${ }^{42}$ Article 2, Ibid.
} 
Makam Sultan Agungan Ngayogyakarta; m. Makam Kutho Gedhe Ngayogyakarta sarta Hastarenggo; n. Pasareyan Giring; o. Makam Giriloyo; p. Makam Wot Galeh; q. Makam Pakuncen; r. Makam Banyu Sumurup; s. Makam Gunung Buthak; t. Makam Widoro Manis; u. Petilasan-Petilasan; v. Pasanggrahan-Pasanggrahan; dan w. Masjid-Masjid Kagungan Dalem. Tanah Keprabon Paku Alaman terdiri dari : Pura Pakualaman; $b$. Masjid Besar Pakualaman; c. Alun-alun Sewandanan; d. Kepatihan Pakualaman; e. Labuhan Glagah Kulon Progo; f. Makam Girigondo Kulon Progo. g. Rumah Bintaran Wetan; h. Makam Gunung Ketur; i. Rumah Dinas Kecamatan; j. Kompleks Pasareyan Sosrobahu; k. SD N Puro Pakualaman; I. Komplek Pasareyan dan Masjid Sonyaragi; $m$. Komplek LP Wirogunan; n. Rumah Jabatan Kepala LP Wirogunan; o. Makam Sentulrejo; dan p. Makam Prajurit Warungboto." 43

Land is not Keprabon or Dede Keprabon ${ }^{44}$ consist of :

- village land originating from the Sultanate and Duchy with Anggaduh rights;

- land that has been used by the community/institution and already has Serat Kekancingan; Article 1 Paragraph (3) "Serat Kekancingan is a decree regarding the granting of land rights from the Sultanate or Duchy to the community/institution which is granted within a certain period of time and can be extended/renewed", consisting of land: a. Magersari; b. Ngindung; c. Anganggo; dan d. Anggaduh.

- land that has been used by the community/institution and does not yet have Serat Kekancingan;

- unused land.

Furthermore, Village land as referred to in paragraph (1) letter a, its existence is based on the Village or Kelurahan parcel maps and supporting data. Serat Kekancingans as referred to in paragraph (1) letter b and letter $\mathrm{c}$, are in the form of: a. Magersari; $b$. Ngindung; c. Anganggo; dan d. Anggaduh. "Magersari land is customary rights granted to the community as residents/users of the Sultanate Land and/or Duchy Land where between the occupants/users of the land there are historical ties and granted only to indigenous Indonesian citizens for a period of time as long as they inhabit/use. "Ngindung" is a customary right granted by the Sultanate or Duchy to the community or institution to use Non-Keprabon Land or Dede Keprabon over the Sultanate Land or Duchy Land by making an agreement whose term is mutually agreed upon; "Anganggo" is a customary right granted by the Sultanate or Duchy to the community or institution to use Non-Keprabon Land or Dede Keprabon without collecting the results and is independent; ${ }^{45}$

Perdais No. 1 of 2017 also regulates: Management of Sultanate land and Duchy land, including administration (Articles 9-14), document maintenance (Article 15), supervision (Articles 16-18). It also regulates the utilization (Article 19-24) and the participation of Regional Government, Regency/City Government and Village Government (Article 2428). If there is a dispute regarding the management and utilization of the Sultanate Land and Duchy Land, between the Sultanate or Duchy and the community/institution, then the handling is carried out based on deliberation and consensus facilitated by the Regional Government. And if consensus is not reached, then the settlement is carried

\footnotetext{
${ }^{43}$ Article 6-7, Ibid.

${ }^{44}$ Article 2, Ibid.

${ }^{45}$ Elucidation of Article 8, Perdais No. 1 Of 2017
} 
out based on the provisions of the legislation (Article 30) Based on the DIY Administration Bureau, until 2005 the amount of land for SG and PAG was more than 6000 ha $(60,000,000 \mathrm{~m} 2)^{46}$ (Endriatmo Soetarto (ed). 2009): 171-173). Another source is Himmah Magazine Edition II of 2002, until 2002 the area of SG and PAG covers an area of 37,782,661 m2. ${ }^{47}$ ((Endriatmo Soetarto (ed). 2009): 171-173) Consists of the city of Jogja covering an area of 2,055,809 m2; Kulon Progo: 8,374,928 m2; Bantul : 18,433,375 m2; Sleman : 2,520,414 m2 and Gunung Kidul with an area of 6,398,135 m2. The huge difference in numbers above proves that SG and PAG soils still pose problems, especially identifying which ones are SG and PAG.

The latest data that we get is that the Sultan Ground and Pakualaman Ground are spread throughout the Special Region of Yogyakarta, as follows ${ }^{48}$ (Rangga Alfiandri, 2016):

Table III.1 Sultan Ground and Pakualaman Ground in DIY

\begin{tabular}{llrr}
\hline No & District Location & Area (m2) & Percentage \\
\hline 1 & Yogyakarta City & 82,000 & 0.16 \\
\hline 2 & Bantul Regency & $22,767,859$ & 44.97 \\
\hline 3 & Sleman Regency & 928,338 & 1.83 \\
\hline 4 & Kulon Progo Regency & $26,451,247$ & 52.24 \\
\hline 5 & Gunung Kidul Regency & 402,950 & 0.80 \\
\hline Amount & $50.632,394$ & $100 \%$ \\
\hline
\end{tabular}

Source: Results of Inventory Activity-Bureau of Governance of the Regional Secretariat of DIY, 2014

\subsubsection{Spatial}

In spatial planning, Act No. 13 of 2012 stipulates that the authority of the Sultanate and the Duchy is limited to the management and utilization of the land of the Sultanate and the Duchy, by establishing a general framework for the policy on spatial planning of the lands of the Sultanate and Duchy in accordance with the Specialties of DIY by taking into account the national spatial layout and spatial planning of DIY (Article 34). . The Spatial Planning of the Sultanate and Duchy Lands is organized based on the following principles: a. recognition of origin rights; b. democracy; c. democracy; d. government effectiveness; and e. utilization of local wisdom. The purpose of regulating the Spatial Planning of Sultanate Land and Duchy Land is to: a. cultural development; b. social interests; and c. community welfare and for environmental sustainability and is used to build harmonization with other spatial units ${ }^{49}$ (Article 2-3) Perdais No. 2 of 2017.

In Perdais No. 2 of 2017 Article6 (1) states that "The policy of realizing the Spatial Planning of the Sultanate Land and Duchy Land in the city core area follows the Catur Gatra Tunggal philosophy, consisting of (a). four elements forming the identity of the city, namely: 1 . Karaton as the center of government; 2 . The square as a center for socio-

\footnotetext{
${ }^{46}$ Endriatmo Soetarto (ed). 2009. Keistimewaan Yogyakarta : Yang Diingat dan Yang Dilupakan, Sekolah Tinggi Pertanahan Yogyakarta p. 171-173

${ }^{47}$ Ibid., p. 171-173

${ }^{48}$ Rangga Alfiandri Hasim, Politik Hukum Pengaturan Sultan Ground Dalam Undang-Undang No. 13 Tahun 2013 Tentang Keistimewaan Yogyakarta Dan Hukum Tanah Nasional, ARENA HUKUM Volume 9, Nomor 2, p. 207-224

${ }^{49}$ Article 2-3 Perdais No. 2 of 2017.
} 
cultural activities; 3 . The Great Mosque as a center for spiritual activities; and 4. Market as the center of economic activity. (b) there is a core part of the city, namely Kutha Gara. The spatial pattern directions in the Sultanate Land Strategic Spatial Unit and the Duchy Land Strategic Spatial Unit are used for several things, as regulated in Article 10, as follows: "a. maintain the cultural heritage architecture; $b$. harmonize the architecture of the building with the architecture of the cultural heritage; $c$. increase cultural potential; d. protect social and religious interests; e. encourage the improvement of community welfare; $f$. controlling the use of Space; g. improve environmental protection; $h$. controlling the sustainable use of natural resources; i. improve the conservation of water resources; and/or j. protect the public from disaster risk." 50

The Sultanate Strategic Space Unit on Keprabon Land consists of: " $a$. Karaton; $b$.

Makam Raja-Raja Mataram di Imogiri; c. Sumbu Filosofi dari Tugu Pal Putih sampai dengan Panggung Krapyak; d. Masjid dan Makam Raja Mataram di Kotagede; e. Masjid Pathok Nagoro; f. Gunung Merapi; dan g. Pantai Samas - Parangtritis. Satuan Ruang Strategis Kasultanan pada Tanah Bukan Keprabon meliputi : a. Kerto - Pleret; b. Kotabaru; c. Candi Prambanan - Candi ljo; d. Sokoliman; e. Perbukitan Menoreh; f. Karst Gunungsewu; dan g. Pantai Selatan Gunungkidul. "(Pasal 11) Karaton berfungsi sebagai pusat sistem spasial dari aspek spiritual dan budaya."

Spatial arrangement of the Sultanate Land and Duchy Land is carried out in a harmonious, integrated manner with other spatial units that have special values in one area. (Article 47) The Spatial Planning of the Sultanate and Duchy is carried out by:

"a. Local government; b. Sultanate/Duchy; c. Regency/City Government; d. Village Government or other designations; and/or e. public. These activities can be in the form of: a. care and maintenance of cleanliness, facilities, infrastructure and supporting facilities; b. Area promotion; c. community empowerment; and D. fostering, supervising, monitoring, and controlling the peace and order in the area." 52

General Explanation of Perdais No. 2 of 2017 it is stated that "DIY Special Spatial Planning is organized based on the privileged values of harmony, environmental sustainability, socio-economic (hamemayu hayuning Bawana), spiritual-transcendent principles (sangkan paraning dumadi), humanism, democratic leadership principles (manunggaling kawula lan Gusti), principles of togetherness (throne for the people), the principle of environmental harmonization (the imaginary axis of the South Seas of the KratonGunung Merapi), historical obedience (the philosophical axis of the Tugu-Panggung Krapyak), the philosophy of the core of the city (chess gatra Tunggal) and the principle of spatial delineation (state path).$^{53}$

Regulation of the Special Region of Yogyakarta in Act No. 13 of 2012 concerning the Privileges of the Special Region of Yogyakarta has not changed to what has been regulated in the laws and regulations governing the previous privileges of the Special Region of Yogyakarta, namely Act No. 3 of 1950 in conjunction with Act No. 19 of 1950 in conjunction with Act No. 9 of 1955. The regulation of privileges in the law has not explicitly regulated the substance or areas that are the special authority of the Special

\footnotetext{
${ }^{50}$ Article 10 Perdais No. 2 of 2017.

${ }^{51}$ Article 12 Perdais No. 2 of 2017.

${ }^{52}$ Article 48 Perdais No. 2 of 2017.

${ }^{53}$ General Explanation of Perdais No. 2 Of 2017
} 
Region of Yogyakarta. In Act No. 13 of 2012 concerning the Privileges of DIY, normatively the types of special powers of DIY have been regulated.

The only area that since the beginning of independence has been given the status of "Special Region" as mandated by Article 18 of the 1945 Constitution (before and after the amendment) is the Special Region of Yogyakarta. In contrast to the granting of privileged status to Aceh Province, not since the beginning of the formation of Aceh Province, but the granting of its privileged status was during the reform and democratic transition period through Act No. 44 of 1999 is based more on socio-political considerations because Acehnese society continues to be in turmoil. Furthermore, Ni'matul Huda (2014) explains:

"In the course of the history of the Aceh Government, it turns out that the granting of the privileged status of Aceh is seen as not enough because substantively the implementation of privileges in Aceh Province is the same as other regions in Indonesia. Even the formation of Papua Province since its inception was given the status as an autonomous region by Act No. 12 of 1969 and has no status as a special or special region. The granting of special autonomy status to Papua Province is based more on sociopolitical considerations and not on historical facts (history of integration). "54

Special autonomy differs from special regions, because in special autonomy the differences with other regions are not only in terms of the structure of regional government, but also include differences in the scope of rights, authorities and obligations of the regions, as well as the pattern and proportion of the relationship between the central government and special regions. . ${ }^{55}$ Likewise, DKI Jakarta Province which is a special area that functions as the capital of the Unitary State of the Republic of Indonesia and at the same time as an autonomous region at the provincial level as regulated in Act No. 29 of 2007.

\section{Conclusion}

The granting of asymmetric decentralization in DIY was motivated by philosophical, historical, juridical and sociological factors. First, The Ngayogyakarta Hadiningrat Sultanate joined the NKRI because Sultan Hamengku Buwono IX confirmed his love for the newly formed NKRI, he and the people of Ngayogyakarta gave up some of their power for the greater good. Second, the confirmation of joining the Unitary State of the Republic of Indonesia was proven through the edict of 5 September 1945, proof of its legality from Sultan Hamengku Buwono IX. Third, Recognition is a condition for the meaning of an ethical life that can only be built through an ethically-laden development process, specifically through the struggle for recognition. The struggle of Sultan Hamengku Buwono IX finally succeeded with the granting of the Charter of Position by President Soekarno on August 19, 1945, which was a form of concrete recognition (de facto) into the Unitary State of the Republic of Indonesia.DIY special powers includes (1) filling in the positions of Governor and Deputy Governor; (2) DIY Regional Government Institutions (3) Culture, namely "Ngayogyakarta Hadiningrat Sultanate is the nation's cultural heritage that has been passed down from generation to generation and led by

\footnotetext{
${ }^{54} \mathrm{Ni}$ 'matul Huda, Loc. Cit, p. 108-109

55 Ibid, p.109
} 
Ngarsa Dalem Sampeyan Dalem Ingkang Sinuwun Kanjeng Sultan Hamengku Buwono Senapati Ing Ngalaga Ngabdurrakhman Sayidin Panatagama Kalifatullah, hereinafter referred to as Sultan Hamengku Buwono." (4) Land that the Sultanate and Duchy as legal entities are subject to rights that have ownership rights to land in the Sultanate and Duchy (5) Spatial planning, namely "The policy of realizing Spatial Planning of Sultanate Land and Duchy Land in the city core area follows Single Gatra Chess philosophy.

\section{References}

\section{Journals:}

[1] Aaron Schneider. Decentralization: Conceptualization and Measurement. Studies in Comparative International Development, 2003;38:1

[2] Bayu Dardias Kurniadi, Desentralisasi Asimetris di Indonesia, http://bdardias.staff.ugm.ac.id/wp-content/uploads/2008/06/Desentralisasi-

Asimetris-di-Indonesia-LAN-Bdg-26112012.pdf, downloaded, 28 July 2019

[3] Bayu Dardias Kurniadi ,"Menyiapkan Sultan Perempuan: Legitimasi Langit dan Efektivitas Rezim Sultan HamengkuBuwono X, "Jurnal Masyarakat Indonesia, Vol 42 (1), June $2016, \quad$ p. 33 http://bayudardias.staff.ugm.ac.id/wpcontent/uploads/2017/02/Bayu-Dardias2016-Menyiapkan-Sultan-Perempuan-Legitimasi-Langit-DanKekuatan-RegimSultan-Hemengkubuwono-X.Pdf

[4] Ismu Gunadi Widodo, Sistem Penetapan Gubernur Kepala Daerah Istimewa Yogyakarta dalam Sistem Pemilihan Kepala Daerah berdasarkan Pasal 18 ayat (4) UUD 1945, Jurnal Dinamika Hukum Vol 11 No. 2 May 2011, p. 316-334;

[5] Indra Kesuma Nasution. The Challenge of Decentralization in Indonesia: Symmetrical and Asymmetrical Debate. International Journal of Social Science and Humanity 2016;6:1-7

[6] Jusuf Madubun,Haedar Akib, Jasruddin. The Prototype Model of Asymmetric Decentralization in Providing Public Services to the Island Areas. Mediterranean Journal of Social Sciences, 2017;8: 120-123

[7] Rangga Alfiandri Hasim, Politik Hukum Pengaturan Sultan Ground Dalam UndangUndang No. 13 Tahun 2013 Tentang Keistimewaan Yogyakarta Dan Hukum Tanah Nasional, ARENA HUKUM Volume 9, Nomor 2, Agustus 2016. P. 207-224

[8] Robert Endi Jaweng, Kritik Terhadap Desentralisasi Asimetris di Indonesia", Jurnal Analisis CSIS, Vol 40. No. 2, June 2011

\section{Books:}

[1] Abu Daud Busroh, Ilmu Negara, First Edition, Jakarta : Bumu Aksara, 1990

[2] Aidul Fitriciada Azhari. Rekontruksi Tradisi Bernegara Dalam UUD 1945. Yogyakarta: Genta Publishing. 2014

[3] Djoko Sukisno. 2011. Disertasi, Kedudukan Kasultanan Yogyakarta Sebagai Subjek Hak Atas Tanah Sebelum Dan Sesudah Berlakunya UU No. 5 Tahun 1960 Di Daerah Istimewa Yogyakarta , FH UNDIP

[4] Endriatmo Soetarto (ed). 2009. Keistimewaan Yogyakarta: Yang Diingat dan Yang Dilupakan, Sekolah Tinggi Pertanahan Yogyakarta 
[5] Kelsen, Hans, Introduction to the Problems of Legal Theory (Clarendon PressOxford), penerjemah Siwi Purwandari, Pengantar Ilmu Hukum, Bandung : Nusa Media,2012

[6] Khudzaifah Dimyati dan Kelik Wardiyono, Metode Penelitian Hukum, Surakarta : FH UMS, 2014

[7] Monfries, John , A Prince in a Republic: The Life of Sultan Hamengku Buwono IX of Yogyakarta, Singapore : Institute of Southeast Asian Studies, 2015

[8] Ni'matul Huda, Daerah Istimewa Yogyakarta dalam Perdebatan Konstitusi dan Perundang-undangan di Indonesia. Bandung: Nusa Media, 2013.

[9] Ni'matul Huda, Desentralisasi Asimetris dalam NKRI, Bandung : Nusa Media, 2014

[10] Peter Mahmud, Penelitian Hukum, Jakarta : Kencana, 2017

[11] Peter Carey, Pengantar buku Soemarsaid Moertono, Negara dan Kekuasaan di Jawa Abad XVI-XIX, Jakarta: Kepustakaan Populer Gramedia, 2018, p. xV

[12] Sidharta, Hukum Penalaran dan Penalaran Hukum, Yogyakarta : Gentha Publishing, 2013

[13] Soedarisman Poerwokoesoemo. 1985. Kasultanan Yogyakarta, Yogyakarta: Gadjah Mada University Prees. 1985

[14] Soedikno Mertokusumo, Perundang-undangan Agraria Yogyakarta, Yogyakarta : Liberty, 1998,

[15] Sujamto, Daerah Istimewa Dalam Negara Kesatuan Republik Indonesia, Jakarta : Bina Akasara, 1988

\section{Regulations:}

[1] Act No. 3 of 1950

[2] Act No. 13 of 2012

[3] Special Regional Regulation No. 1 of 2013

[4] Special Regional Regulation Number 1 of 2015

[5] Special Regional Regulation No. 2 of 2015

[6] Special Regional Regulation No. 1 of 2017

[7] Special Regional Regulation No. 2 of 2017

[8] Special Regional Regulation No. 3 of 2017

[9] Special Regional Regulation No. 1 of 2018

\section{Interview:}

[1] Interview with Peter Carey, International Symposium on Javanese Studies and Manuscript of Yogyakarta Palace, Royal Ambarukmo Yogyakarta, 5-6 March 2019

[2] Interview with Afnan Hadikusumo, DPD RI member of the DIY Dapil, July 27, 2019 